-Araştırma Makalesi-

\title{
Mimarlık ve Sinema Arakesitinde Yer ve Yersizliği Okumak: Ahlat Ağacı Filmi'nde Ruhun Yitimi
}

\author{
Gülşen Ergün Bilgili* \\ Pınar Dinç Kalayci**
}

\section{Özet}

Norberg-Schulz'a (1980) göre; insan, içinde gezinebildiğinde ve kendini bir çevre ile tanımlayabildiğinde ya da kısacası çevreyi anlamlı olarak deneyimleyebildiğinde yaşar. Insan doğayla, toprakla kök salmaya, 'yer'leşmeye uğraşır. Mimarlık da 'yer'den başlar. Yer, mimariyi barındırır, yaratır ve dönüştürür. İnşa ve iskan, insanın 'yer'deki 'şey'lerle ilişkisi ve yeri anlamlandırma çabalarn ile ilişkilidir (Heidegger, 1971). Yersizleşmeye başlayan bir yapılı çevrede kimlikli bir yaşam inşa etmenin olanaksızlaşmaya başladığın tartışan ve yersizleşmeyi eleştirel pencere aralayan bir kavram ve bir problem olarak ele alan çalışma, problemi mimarliğın yalnızca salat plastik biçimine yani mekânsal özelliklerine indirgemediği; aynı zamanda sinemanın eleştirel dili araculığıyla, anlamsal biçimi yani ruhsal yanıyla anlamaya çalışması ile diğer çalışmalardan ayrılır. Çalı̧̧ma, sinema ve mimarlık disiplinlerinin düşünsel arka yapılarım bir araya getirerek yersizleşme kavramını Nuri Bilge Ceylan'ın Ahlat Ağacı (2018) filmi özelinde örnekler; yer tartışmalarmın temel literatürünü oluşturduğu için Heidegger, ilk defa yerin ruhu kavramın ortaya koyduğu için Norberg-Schulz ve yersizleşmeyi insan deneyimi ile birlikte tartıştığı için Relph'in yer-yersizlik tartışmalarını, ruhun yitimi ile ilişkilendirir; ruhun yitimini, (i) eylemlerin gerçekleştiği alan, (ii) bölge, yöre, ev, (iii) kimlik, karakter, varlık olmak üzere üç başlıkta toplanan kavramlar aracılığıyla analiz eder; her bir kavrama denk gelen sahne ve diyaloglarn inceler. Çalışmanın ana kabulü, yersizleşmenin, ruhun yitimi ile ilintili olduğu; ruh yitiminin de yalnızca yerin ruhunun (genius loci) yitimi değil aynı zamanda insanın ve devamında toplumun ruhunun yitimini beraberinde getirdiğidir. Modernizm ile başlayan, postmodernizm ile şekil değiştiren ve içinde bulunduğumuz hızlı tüketim çağı ile birlikte de farklı noktalara taşınmasıyla güncelliğini koruyan ve disiplinlerarası eleştirel incelemelere argüman oluşturan yersizleşme problemi çalışmada; sinema-mimarlık disiplinlerini kesiştirmekte, ruhun yitimi ve bu yitimin deşifresini sağlayan kavramların, bir bütün olarak gelecek sinema-mimarlık çalışmalarn için bir model olarak önermektedir.

Anahtar Kelimeler: Yer, Yersizlik, Mimarlık, Yerin Ruhu, Nuri Bilge Ceylan, Ahlat Ağacı.

\footnotetext{
*Mimar, Gazi Üniversitesi, Mimarlık Fakültesi, Mimarlık Bölümü Ankara, Türkiye.

E-mail: g.ergun39@gmail.com

ORCID : 0000-0002-1330-0227
}

**Prof.Dr. Gazi Üniversitesi, Mimarlık Fakültesi, Mimarlık Bölümü Ankara, Türkiye.

E-mail: pinarpinardinc@gmail.com

ORCID : 0000-0002-1932-9477

DOI: 10.31122/Sinefilozofi.823794

Ergün Bilgili, G., Dinç Kalaycı, P. (2021). Mimarlık Ve Sinema Arakesitinde Yer Ve Yersizliği Okumak: Ahlat Ağacı Filmi'nde Ruhun Yitimi. Sinefilozofi Dergisi, Cilt: 6, Say1: 12. 1025-1043. https//doi.org//10.31122/Sinefilozofi.823794

Geliş Tarihi: 09.11.2020

Kabul Tarihi: 08.12.2021 
-Research Article-

\title{
Reading Place and Placelessness at the Intersection of Architecture and Cinema: Loss of the Spirit in Ahlat Ağacı (The Wild Pear Tree)
}

\author{
Gülşen Ergün Bilgili* \\ Pınar Dinç Kalayc1**
}

\begin{abstract}
According to Norberg-Schulz (1980); man lives when he can navigate within and identify himself with an environment, or in short, experience the environment meaningfully. Man tries to take root and dwells in nature and land. Architecture starts from 'place'. The place accommodates, creates, and transforms architecture. Building and dwelling are linked to man's relationship with things in place and his efforts to make sense of the place (Heidegger, 1971). Discussing that it has become impossible to build a life with an identity in a built environment that has started to become displaced, the study, which deals with dislocation as a concept and a problem that opens a critical window, argues that the problem does not reduce the purely plastic form of architecture, that is, its spatial characteristics; At the same time, it differs from other works in that it tries to understand the semantic form, that is, its spiritual side, through the critical language of cinema. This study, by bringing together the intellectual backgrounds of the disciplines of cinema and architecture, exemplifies the concept of placelessness in the context of Nuri Bilge Ceylan's Ahlat A ğacu (The Wild Pear Tree, 2018) movie; relates Heidegger, as it constitutes the basic literature of place discussions, Norberg-Schulz for introducing the concept of the spirit of place for the first time, and Relph's because he discusses placelessness together with human experience, discussion of place and place with the loss of the spirit; analyzes the loss of the spirit through concepts gathered under three headings: (i) space where the actions take place, (ii) district, region, home, (iii) identity, character, existence; and examines the scenes and dialogues that correspond to each concept. The main acceptance of the study is that placelessness is related to loss of the spirit; is that the loss of the spirit is not only the loss of the spirit of the place (genius loci), but also the loss of the spirit of the human and subsequently of the society. In the study, the problem of placelessness, which started with modernism, changed shape with postmodernism, and which continues to be up-to-date by being moved to different points with the age of fast consumption we are in, and which constitutes an argument for interdisciplinary critical studies; intersects the disciplines of cinema and architecture, and proposes the concepts of loss of the spirit and deciphering this loss as a model for future cinema-architecture studies as a whole.
\end{abstract}

Key Words: Place, Placelessness, Architecture, Spirit of the Place, Nuri Bilge Ceylan, The Wild Pear Tree.

\footnotetext{
*Architect, Gazi University, Faculty of Architecture, Department of Architecture, Ankara, Turkey

E-mail: g.ergun39@gmail.com
}

ORCID : 0000-0002-1330-0227

\footnotetext{
**Prof.Dr. Gazi University, Faculty of Architecture, Department of Architecture, Ankara, Turkey.

E-mail: pinarpinardinc@gmail.com

ORCID : 0000-0002-1932-9477

DOI: 10.31122/Sinefilozofi.823794

Ergün Bilgili, G., Dinç Kalaycı, P. (2021). Mimarlık Ve Sinema Arakesitinde Yer Ve Yersizliği Okumak: Ahlat Ağacı Filmi'nde Ruhun Yitimi. Sinefilozofi Dergisi, Cilt: 6, Say1: 12. 1025-1043. https//doi.org//10.31122/

Sinefilozofi.823794
}

Recieved:09.11.2020

Accepted: 08.12.2021 


\section{Extended Abstract}

When architecture begins to exist from a 'place', that is, when it starts from 'place' and extends to an architectural product, it begins to be associated with all the values of human existence. According to Norberg-Schulz (1976), the place is a qualitative "total" phenomenon whose concrete nature cannot be ignored or reduced to any feature such as spatial relationships. According to Relph (1976); the essence of place does not come from location, function, or society but from experiences that define specific places like the deep centers of human existence, and largely from unconscious purposes. The place is both a total phenomenon and related to every 'thing' that is related to man. According to Relph (1976), placelessness is the result of the dominance of artificial approaches, the weakening of the identity of places to the points where they do not only resemble each other but also make men feel the same by offering similar possibilities for experiences. In other words, placelessness is the state of losing the concrete properties of the place, as well as the loss of the meaning of the place related to humans and related to human relationships and experiences. In ancient Rome, it was believed that God gave a spirit to people and places and this spirit kept people and places alive (Norberg-Schulz, 1980). All kinds of interactions of the place with human experiences and everyday life create a spirit. This spirit develops, transforms, and disappears with the spirit of the place. The main acceptance of the study is that placelessness is related to loss of the spirit; is that the loss of the spirit is not only the loss of the spirit of the place (genius loci), but also the loss of the spirit of the human and subsequently of the society. This study, by bringing together the intellectual backgrounds of the disciplines of cinema and architecture, exemplifies the concept of placelessness in the context of Nuri Bilge Ceylan's Ahlat Ağacu (The Wild Pear Tree, 2018) movie; relates Heidegger, Norberg-Schulz and Relph's discussion of place and place with the loss of the spirit; analyzes the loss of the spirit through concepts gathered under three headings: (i) space where the actions take place, (ii) district, region, home, (iii) identity, character, existence; and examines the scenes and dialogues that correspond to each concept. Like all other branches of art, architecture and cinema are not independent of meaning. Each work of art contains meaning and expression in itself. Although cinema and architecture are seen as visual arts, both arts contain literary foundations in their depths by searching for meaning in form of art, questioning the way of being, and making the audience question. Therefore, the review is conducted through scenes and dialogues in response to both spatial and spiritual titles. The basis of this review on the concepts of place and placelessness is the reading of the components of the concept of place through film. From these titles, the area in which actions take place is relatively more spatial features of the 'place', it can be characterized as a specialized/marked place in the context of action and culture. We can talk about the coexistence of both spatial and spiritual features for the district-region and home. Identity-character and existence are spiritual and qualitative features of the "place", it is the situation where personalities and identities find reflection in the qualities of the place. The method of the study is based on the intersecting of keywords for three concepts determined based on these concepts with five characteristic scenes and five characteristic dialogues, which are selected as determinants for sampling from the film. After the intersection, concepts are analyzed for each scene and dialogue. Of these concepts and keywords of concepts, (i) space where the actions take place; (i-i) location (in/out/opposite...), (i-ii) inclusiveness/exclusion, (i-iii)functional and cultural differentiation , (i-iv)creating memories, information, memory, archives can also be viewed in scenes (ii)districtregion-home; (ii-i) natural/Man-made, (ii-ii) countryside/urban, (ii-iii) created/ manufactured, (ii-iv) creating the cosmos, (ii-v) the dialectical balance between escape and stay can be viewed in scenes and dialogues; (iii) identity-character-existance; (iii-i) abstract/concrete description, (iii-ii) set of adjectives, (iii-iii) lived, shared, replicated, (iii-iv) comprehension through experience, (iii-v) Societal-individual existentialism can be viewed in dialogues. As a result of the analysis, the concept of "loss of the spirit" is suggested concerning three sub-concepts. The concept of "loss of the spirit" emerged by intersecting and moving one step further Norberg-Schulz's concept of "the spirit of place (genius loci)" and the concept of "placelessness" that emerged as a result of various semantic studies. The loosing of the spirit is that the loosing of the spirit of the place is followed by the loosing of the spirit of the man "in that place" and, in parallel, the loosing of the spirit of the society. The loosing of the spirit and the five concepts that enable the deciphering of this loss as a whole are a model proposal for future cinema-architecture studies. The presence or absence of these concepts can raise original analysis deeply inquiring the dialogues and scenes of movies, therefore give birth to different models that are based on this model for further readings. 


\section{Giriş}

Mimarlık ve sinema sıklıkla görsellik paydasında buluşturulur. Bazin (2011, s. 20), sinemayı zamanın tarafsızlığı olarak tanımlamakta, sinema sanatını resimden ayıran en önemli özelliğin ise işin içine 'zaman' boyutunun katılması olduğunu vurgulamaktadır. Ayr1ca Bazin'in vurguladığı üzere; resim görüntü oluşturarak bir sanat yaratmakta, fotoğraf ve sinema ise gerçeklik düşüncesini sağlayan icatlar olarak öne çıkmaktadır. Bu noktadan ele alındığında, sinema için de iki önemli unsur 'zaman' ve 'mekân' dır. Mimarlık için de önemli noktalarda bulunan 'zaman' ve 'mekân' unsurları bir arada değerlendirildiğinde; 'yer' kavramı inceleme alanına girmektedir. Dolayısıyla mimarlık kuramlarında geniş yer tutan; yer, yerellik, yerin ruhu ve yersizlik tartışmaları sinema sanatı üzerinden de mimarlıkla ilişkilendirilebilir ve tartışılabilir.

Genel çerçevede bakıldığında sinema daha çok mimarlığın 'mekânsal' ve 'fiziksel' özellikleri ile ilişkilendirilmektedir. Sinemada kullanılan çekim teknikleri -kadraj, renk, ışık kullanımı çekim açısı vb.- ile bağlantılar kurulmakta, gerçek mekânların sinemasal dilde yeniden üretimi araştırma konusu olmaktadır. Wes Anderson filmlerindeki renk-mekân-anlatım ilişkisi (Canbolat ve Öner, 2019); mekân ve algının perspektif, 1şık, kompozisyon ile Uzak (Nuri Bilge Ceylan, 2002) filmi üzerinden incelenmesi (Ergin, 2007); Berlin Yahudi Müzesi'nin Schindler's List (Schindler'in Listesi, Steven Spielberg, 1993) filmi üzerinden çözümlenmesi (Bala, 2019) gibi örnekler mimarlık-sinema arakesitindeki arayışlara örnek oluşturmaktadır. Sinemanın -1928'e kadar sessiz olmasının da etkisiyle- görsel yönü, anlatımsal-sözlü yönünün bir adım ilerisinde olmuştur. Bazin (2011, s. 36), gerçek veya montaj, birincil rolün görsel imaj olduğunu, sesin tamamlayıcı ve ikincil bir rol oynadığını vurgulamaktadır. Ancak, sinema imgesel olduğu kadar öyküsel de olup edebiyatla da güçlü bağ kurmaktadır. Sinema, gerek imajlar aracılığıyla gerekse de anlatım aracılığıyla bir hikâye anlatır.

Sinema sanatı zaman içinde farklı tekniklerin, düşüncelerin, akımların etkisiyle farkl1laşmıştır. Akbulut (2005, s. 43), Ceylan Sineması'nın Deleuze'un tanımladığı hareket-imge ve zaman-imge başlıklarından, bizi hayatın oluşu ve dinamizmi ile yüzleşmeye iten "zamanın kendisinin sunumu" olarak tanımlanan zaman-imge sinemasına dâhil olduğunu vurgulamaktadır. Akbulut'a göre Ceylan Sineması'nda "ölü anlar" olarak tanımladığı zamansal boşluklar, hem zaman üzerine hem de yaşama dair bizi düşünmeye itmektedir.

Ahlat Ağacı'nda, Ceylan'ın; Mayıs Sıkıntısı (1999), Kasaba (1997), Kış Uykusu (2014) gibi filmlerine benzer şekilde, "taşraya dönüş" yaşanmaktadır. "Ev", "çocukluk" ve "kasaba-kent" meseleleri Ceylan'ın filmlerindeki en temel meseleler olarak göze çarpmaktadır (Ergin, 2007, s. 60). Ceylan' in filmleri genel çerçevede bakıldı̆̆ında, birçok incelemeye de konu olmuş "taşra" ve "kent" ilişkisi ve bu ilişkiler içinde sıkışmış karakterler üzerine kurgulanmıştır. Ceylan senaryoyu oluştururken Akın Aksu'ya ait "Ahlat'ın Yalnızlığı" isimli öyküden yola çıkmıştır. Ana karakter Sinan, üniversiteyi bitirir ve büyük şehirden (Çanakkale) kendi küçük kasabasına (Çanakkale'nin Çan ilçesi) bir kitap yayınlatma hayaliyle döner. Filme ve Sinan'ın yayınlatma hayali kurduğu kitaba da adını veren 'Ahlat Ağacı', taşrayı, yalnızlı̆̆ı, var-olma çabasını simgeler. Ayrıca 'Ahlat Ağacı' nın 'yer'e, taşraya veya daha küçük ölçekte kasabaya kimlik kazandırdığı veya bir simge oluşturduğu da söylenebilir. Ceylan, yapılı çevreyi bir anlatım aracı olarak kullanmaktadır. Anlatıda kullanılan taşra ve kent karşıtlığı ve bu karşıtlığın neden olduğu karakteristik muğlaklık adeta bir 'var-olma' mücadelesidir. Hayatta kendine bir 'yer' arayan karakterler, bu karakterlerin 'aidiyet'inin sorgulatılması yapılı çevreler aracılığıyla aktarılmaktadır. Döndüğü kasabada değişen yerler, değişen karakterler ve neticede de Sinan'ın kendisinin değişmesi; ana karakterin diğer karakterlerle yaşadığı çatışmalar, mekânlarla yaşadığı gergin ilişki filme konu olmaktadır. Bir yandan, mesleğini yapabilmek için çabalaması, bir yandan yazdığı kitabı bastırmak için kapı kapı dolaşması, bir yandan da hayatındaki insanlar ile yaşadığı diyaloglar filmde işlenmektedir. Ahlat Ağacı'nda anlatım Sinan'ın üzerinden, farklı karakterlerle yaptığı sohbetler ile sürüp gitse de esas önemli nokta, Sinan'ın bu diyalogları gerçekleştirdiği ortamlardır. Yani, Sinan konuşurken ve dinlerken sü- 
rekli bir akış içerisindedir. Bazen akış Sinan'ın arkadaşıyla yaptığı telefon konuşması esnasında köyde yürümesiyle sürüp giderken bazen şehirde karşılaştı̆̆ 1 yazarla konuşmasında şehrin sokaklarında yürümesiyle sürmektedir. Bu akış anlatımlar ile birleşince anlam bir manifestoya dönüşmektedir

Öztürk'ün (2018, s. 229) filmi, “yüce bir dış ses"in onaylanması adına diyaloglarla donatılması ve bu diyalogların araçsallaşmasını filmin sorunu olarak görmesinin aksine; Tekeş'in (2019) edebiyat ve kutsal kitaplara yapılan göndermelere dikkat çekerek, anlatının bunlarla güçlendirildiğini ve odak noktaya alındığını vurgulaması gibi, sinemanın anlatısal yönünü daha kuvvetli kullanmakta ve işlemekte olduğunu vurgulayan eleştirmenler ve yorumcular bulunmaktadır. Ceylan'ın sineması diyalog ve monolog açısından zengin olmasıyla film, tiyatro ve öykü/roman arasındaki ilişkiyi yeniden kurgulamaktadır. Nitekim Ceylan, kendisinin de katkısını kabul ettiği üzere Rus yazar Anton Çehov edebiyatına da öykünmektedir (Diken, Gilloch, \& Hammond, 2018, s. 21) Diğer filmlerine göre Ceylan, Ahlat Ağaci'nda diyalogları daha yoğun kullanmıştır; bunun bilinçli bir seçim olduğunu ve bunu da sinemada farklı bir deneyim olarak değerlendirdiğini vurgulamaktadır (Ceylan, 2018).

\section{Çalışmanın Kapsamı, Sınırlılıkları ve Yöntemi}

Sinema, hem yarattığı hem de içinde bulunduğu zamanın kültürel arkeolojisini ortaya çıarmaktadır (Pallasmaa, 2008). Kültürel arkeoloji bağlamında ele alındığında sinema, mimarlık için hem bir tarihsel dayanak sunmakta hem de güncel mimarlık kuramlarına altlık hazırlamaktadır. İnceleme, kültürel arkeoloji anlamında ve gerçekliği sergileme yönünden güçlü bir sanat dalı olan sinema üzerinden yürütülerek; belirlenen 3 kavramın tartışma zemini oluşturulmuştur. Yapılı çevre ve insanı ustalıkla sergileyen sinema sanatı içinde ise çalışmaya eleştirel bir çerçeve sunabilen bir örnek seçilmesi amaçlanmıştır. Bu yüzden, filmlerinin genelinde dikkat çekici bir şekilde kır-kent gerilimleri, arada kalmışlık ve bulunduğu yeri sorgulayan, sınırlarını tartışan bir yaklaşıma sahip olan Nuri Bilge Ceylan sineması seçilmiş̧ir. Bu inceleme için ise; özellikle hem diyalogların (ruhsal olanın) görece daha fazla olduğu hem de inceleme için sahnelerin ciddi görsel bir altyapıya (mekânsal olana) sahip olduğu için "Ahlat Ağacı" filmi seçilmiştir. Diyalogların, Deleuze'ün modern sinema tanımında kullandığı zaman-imaj tanımlamasını zayıflatabileceği düşünülse de imajların/sahnelerin ve diyalogların çakıştırılarak deşifre edilmesi, 'yer'bağlamında bir inceleme için anlamlıdır. Buna bağlı olarak, salt imaj/ sahne çözümlemesi yapılmamış, filme karakterini veren ve yer/yersizlik bağlamında anlam ifade eden diyaloglar, kimi zaman bağımsız kimi zaman da sahnelerin içinde eritilmiş, destekleyici ve anlatımsal yönü kuvvetlendiren veriler olarak incelemeye dahil edilmiştir. Ceylan'ın sinemasının en can alıcı ve bu inceleme için önemli noktası ise filmlerinin zamana ve mekâna odaklanan bir anlatım içermesi, mesaj iletme aracı oluşturmasıdır.

Yer ve yersizlik kavramları üzerinden yapılan bu incelemenin temelini, yer kavramının bileşenlerinin film üzerinden okunması oluşturmaktadır. Yer kavramının bileşenleri üç ana başlıkta toplanmıştır: (i) eylemlerin gerçekleştiği alan; (ii) bölge, yöre, ev; (iii) kimlik, karakter, varlık. Bu başlıklardan; eylemlerin gerçekleştiği alan, 'yer'e ait görece daha mekânsal özelliklerdir, eylem ve kültür bağlamında özelleşmiş/işaretlenmiş yer olarak nitelendirilebilir. Bölge, yöre ve ev için hem mekânsal hem ruhsal özelliklerin bir arada olma halinden bahsedebiliriz. Kimlik-karakter ve varlık ise 'yer' in ruhsal ve nitel özellikleridir, kişiliklerin, kimliklerin yerin niteliklerinde yansıma bulması durumudur.

Öncelikle yer, yerin ruhu, yersiz, yersizlik ve ruhun yitimi ile ilgili genel bir çerçeve çizilmekte daha sonra; film, yer üzerinden tartış1lırken belirlenen ana başlıklar altında parçalara ayrılmaktadır. Filmden belirleyici, beş karakteristik sahne (mekânsal olgu) ve beş karakteristik diyalog (ruhsal olgu) seçilmiştir. Bu sahneler tek bir kare halinde değil, ilgili kavramların üzerinden tartışılmasına olanak verecek şekilde belirli dakikaları kapsayacak şekilde 
değerlendirilmiştir. Seçilen sahneler, belirlenen üç ana kavram ve bu kavramlarla bağlantılı anahtar kelimeler çerçevesinde filmden süzülerek; filmde insan ile doğal veya insan yapımı alanların çakışması ve bu çakışmanın filmin anlatımında yoğun etkili olduğu düşünüldüğü sahneleri kapsamaktadır. Her bir başlık altında, daha çok ana karakter olan Sinan üzerinden tartışmalar yürütülmüştür. Her başlık altında başka yaklaşımlar başka bakış açıları sunulsa da temelde varılan ve varılmak istenen nokta yer ve yer-sizleşme çizgisi olmuştur. Yer ve yerin ruhu üzerinden başlayan inceleme yersizleşme ile sonlanır. Yersizleşme ise yerin ruhunun yitimiyle gerçekleşir. Okumalar, bir sinema filminin kendi eleştirel argümanını oluşturmasında mekânı ve onun önemli bir niteliği olan "yer olma" boyutunu nasıl kullanabildiğini örneklemekte, bu yolla sinema-mimarlık ilişkisinde "ruhun yitimi" olarak adlandırılabilecek özgün bir toplumsal eleştiri boyutunu da aydınlatmaktadır. Deleuze ve Guattari'nin açılımladığ1 üzere; kapitalizmin toplumsal yaşantı üzerinde yansımasını oluşturan yersizyurtsuzlaşma, yeniden yurt edinmeyi devaminda getiren devingen bir oluşumdur (Koçyiğit, 2007, s. 124). Çalışmada önerilen ruhun yitimi kavramı ise yersizleşmeye sebep olan ve yersizleşme sonrasını da içinde barındıran bir süreç olarak değerlendirilmektedir. Yani, örneğin kapitalizm aracılıyla gerçeleştirilen bu yeniden yurtlan-dırıl-ma hali de içinde birçok ruh yitimini barındirmaktadir.

Yer ve yersizleşme üzerine yapılan okumalar çeşitlendirilerek farklı felsefik görüşler aracılığıyla sürdürülebilir. Genel bir çerçeve çizildiğinde oldukça soyut görünecek bu kavramsal okumalar, içinde yerin kavramsal bileşenleri ve yersizin yoksunlukları olarak değerlendirilebilecek ortak anahtar kelimeler barındırmaktadır. Bu anahtar kelimeler incelemeyi okunur kılmak ve somutlaştırmak adına şekil 1'deki gibi gruplandırılarak diyaloglar ve sahneler ile ilişkilendirilmiştir.

\begin{tabular}{|c|c|}
\hline $\begin{array}{l}\text { YER(LEŞME) / YERSİZ(LEŞME) } \\
\text { KAVRAMSAL BİLEŞENLERİ }\end{array}$ & $\begin{array}{c}\text { YER(LEŞME) / YERSİZ(LEŞME) ANAHTAR } \\
\text { KELİMELERİ }\end{array}$ \\
\hline 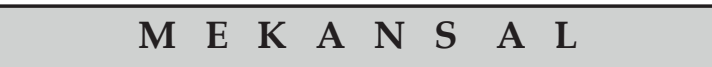 & \\
\hline - EYLEMLERIN GERÇEKLEŞTİĞİ ALAN & 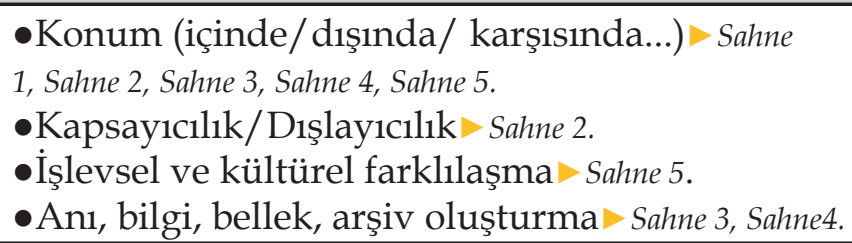 \\
\hline $\begin{array}{llllll} & \text { R } & \text { H } & \text { S } & A & L\end{array}$ & \\
\hline $\begin{array}{l}\text { KIMLIKK } \\
\text { KARAKTER } \\
\text { VARLIK }\end{array}$ & $\begin{array}{l}\text {-Soyut/somut karşılık > Diyalog } 5 . \\
\text { - Sifatlar kümesi }>\text { Diyalog 3, Diyalog } 4 . \\
\text { - Yaşanılan, paylaşılan, çoğaltılan > Diyalog } 1 . \\
\text { - Deneyim yoluyla kavrama > Diyalog } 2 . \\
\text { - Toplumsal-bireysel varoluşça > Diyalog } 2 .\end{array}$ \\
\hline M E K A N S A L + R U H S A L & \\
\hline $\begin{array}{l}\text { BÖLGE } \\
Y O ̈ R E \\
E V\end{array}$ & 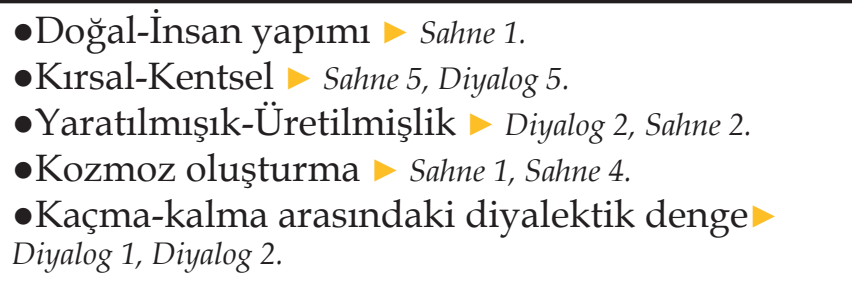 \\
\hline
\end{tabular}

Şekil 1: Çalışmanın teorik çerçeve şeması 


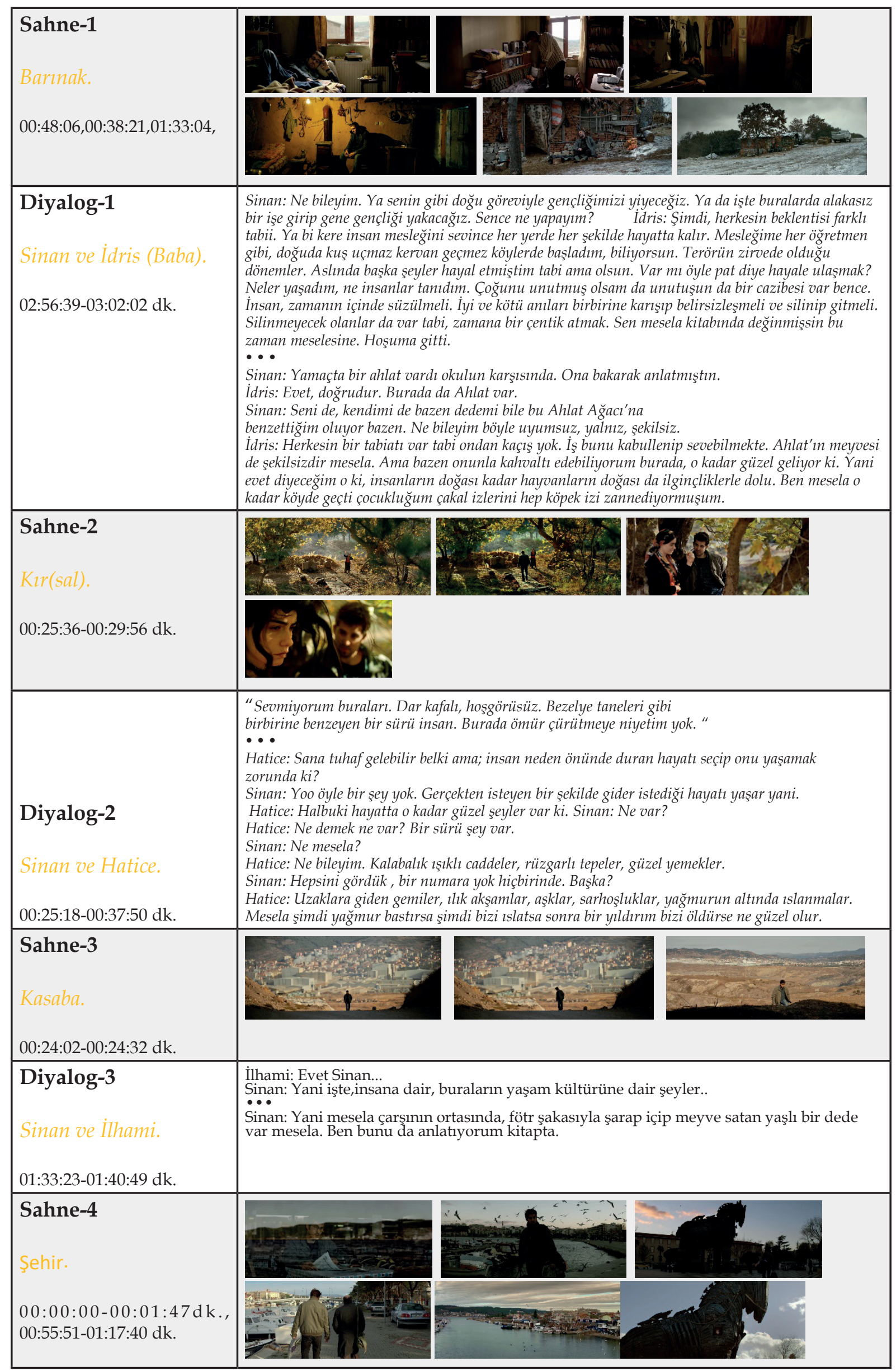




\begin{tabular}{|c|c|}
\hline $\begin{array}{l}\text { Diyalog-4 } \\
\text { Sinan ve Süleyman. } \\
\text { 01:00:05-01:15:39 dk. }\end{array}$ & 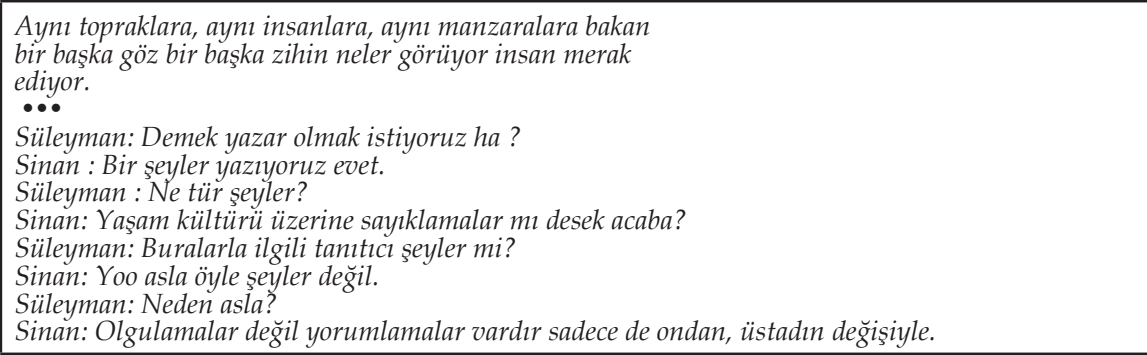 \\
\hline $\begin{array}{l}\text { Sahne-5 } \\
\text { Köy. } \\
\text { 01:58:21-02:18:18 dk. }\end{array}$ & $\left.-2 x^{2}-\pi^{2}\right)$ \\
\hline $\begin{array}{l}\text { Diyalog-5 } \\
\text { Sinan \&Veysel \&Nazmi. } \\
\text { 01:58:21-02:18:18 dk. }\end{array}$ & $\begin{array}{l}\text { Sinan: Nasıl gidiyor yeni cami? } \\
\text { Veysel: Valla hiç bilmiyorum Sinancım. Ihtiyar heyeti yüklendi işi, gidiyor. } \\
\text { Sinan: Büyük büyük camlar, kubbeler, otomatik kapılar vs..?" } \\
\text { •̈• } \\
\text { Veysel: Bütün nehirler azgın çă̆layanlar olarak doğar. Ama hiçbiri köpürerek denizevarmaz. } \\
\text { Sinan: Senin o azgin çağlayanlar olarak doğar dediğin nehirler sonuçta bir sürü çöpü, çall çırpıyı } \\
\text { yanında sürüklemiyor mu? Güçlü karakterlerin de bir sürü ezik, yalaka karakteri yanında sürüklediği } \\
\text { gibi.." }\end{array}$ \\
\hline
\end{tabular}

\section{Yer, Yerin Ruhu, Yersizleşme, Yersizlik Çerçevesi}

Türkçe Sözlük'te yer, farklı şekillerde tanımlanmaktadır. Yer, öncelikle boşluk olarak tanımlanmakta, bu anlamini; gezinilen, ayakla basılan taban; bulunulan, yaşanılan, oturulan bölge; durum, konum, vaziyet; üzerine yapı kurulmaya elverişli arazi, arsa; ekime elverişli toprak parçası, arazi; bir olayın geçtiği veya geçeceği bölüm, alan, mahal anlamları takip etmektedir (TDK,2020). Cambridge İngilizce sözlükte ise yer(place), boşluk; alan; içinde bulunulan durum; yaşanılan bölge ve ev olarak tanımlanmaktadır (Cambridge Dictionary, 2020). Bu ve benzer birçok şekilde tanımlanabilecek olan yer kavramının net ve tamamen somut sınırları bulunmamaktadır. Somut ve soyut olarak içinde bir çok anlam barındıran 'yer' kuramsal alanda da oldukça geniş yer tutmuş ve çok sayıdaki anlamına paralel olarak birçok kavramla ilişkilendirilmiştir.

Norberg-Schulz, çevre için somut terimin 'yer' olduğunu söyler. Eylemlerin ve olayların o yerde gerçekleştiğini söylemenin yaygın bir kullanım olduğunu, ancak, bir yöreye/ bölgeye atıfta bulunmadan herhangi bir olayı hayal etmenin imkânı olmadığını, yerin açıkça varoluşun bir parçası olduğunu vurgular (Schulz, 1980, s. 6). Yani yer, kimliklidir. Bir boşluk, bir hacim tanımlıyor olsa da o boşluğun 'yer' haline dönebilmesine, o boşluğa ait belirleyici özelliklerin öne çıkması neden olur.

İnsanın, yaşamdaki öncelikli amaçlarından biri de bir «yer > edinmektir. En basit anlamda insan, içinde bulunduğu 〈fani〉 çevre içinde tutunmaya çalışır. İnşa etmek ve toprağ işlemek, var olmanın bir parçasıdır (Heidegger, 1971, s.147). Birincil insani ihtiyaç olan barınma ihtiyacının temelinde, yalnızca fiziki çevre koşullarından korunmak değil bir yandan da var olmaya çalışmak yatmaktadır. 'Yer', hem kelime anlamının içeriği açısından hem de temelde insanın toprağ 1 "kendine göre" işlemesi açısından 'ev' ile de ilişkilendirilir (Usta, 2020, s.29). Heidegger'e göre bina, insanın varoluşunu konumlandırır. Bina yerin ve oturanların özelliklerine göre inşa edilir, içinde bulunduğu fiziksel ve beşeri topoğrafyayla şekillenir (Sharr, 2010, s. 10). Bina, insanın özelliklerine göre, şehirler de toplumun özelliklerine göre inşa olunmaktadır. Şehirler, toplumun özellikleri ile inşa olurken bir yandan da toplumun beklentilerine cevap vermek üzere evrilmektedirler. Bir başka deyişle, toplum şehirleri dönüştürür, geliştirir. Toplumun yararı ve beklentileri paralelinde evrilemeyen şehirler 'yer' olma 
özelliklerini de yitirmeye veya 'yer'e ait olamamaya başlarlar. Aynı şekilde 'yersizleşmeye' başlayan toplumlar da ruhlarını yitirmeye başlarlar. Bu karşılıklı ve döngüsel bir yitiştir.

Relph (1976, s.43)., yerin özünü ortaya çıkarmak için; konum (location), peyzaj (landscape or appearance), zaman (time), topluluk/toplum (community/ society), özel ve kişisel yerler(private and personal places), kök salmak veya bağlllık (rootedness or attachment), ev (home), bir angarya olarak yer (the drudgery of place) özelliklerinin deşifre edilmesi gerektiğini ifade eder. Aynı zamanda, bütün bu özelliklerin bir yer için ortak veya gerekli olsa da; yerin özünün, konumdan, işlevden veya topluluktan gelmediğini aksine insan varoluşunun derin merkezleri olarak tanımlanabilecek deneyimlerden ve büyük ölçüde bilinçdışı amaçlardan geldiğini vurgular.

Yer, tektipleşmeye başladığında 'biricik' özelliklerini yitirerek yersizleşmeye başlar. Yersizleşmenin sorunsallaşması, 1960'1 yıllarda başlamış ve bir modernizm eleştirisi olarak kavramsallaşmıştır. İşlevselliğe yönelme, mekânların anlamlarından arınması ve aidiyet hissinin yitirilmesi mimarlıkta yersizleşme tartışmalarını kuvvetlendirmiştir. Relph (1976, s. 80), kırsal yerleşim alanlarından çalışmak için kente giden toplum için kırsalın popülerleşmesinin ardından gelen modernizmi ve postmodernizmi farklı açılardan eleştirmektedir. Modernizm ile birlikte gelen işlevselliğin ön plana çıkması ve yapılaşmanın tektipleşerek her 'yer'e aynı yaklaşımda yapı yapma geleneğini "yersizleşme" olarak değerlendirmektedir. Modernizmin ardından gelen postmodernizm dönemi modernist yaklaşımları eleştirmiş, fakat bu dönemde de içi boşaltılmış, anlamsal bağı olmayan yapılar üretilmiş ve kültür bir müze mantığında yaşatılmaya başlanmıştır. Modernizm 'yersizliğinin' ardından gelen postmodernist dönemde de farklı 'yersizlik'ler oluşmuştur. Modernleşme; değişim hızı ve değişim alanı ile bağlantılı olarak süreksizlik, ait olma özelliğinin yitirilmesine bağlı olarak bağlamından kopma ve toplumsal yaşama ilişkin sistematik ve zihinsel bilgi üretimine bağlı olarak düşünümsellik olmak üzere sosyal yaşantı üzerinde üç temel etki bırakmıştır (Giddens, 1994, s.53).

Yersizleşme, yapay yaklaşımların hâkim olmasının sonucudur. Yersizlik, yerlerin kimliğinin yalnızca birbirine benzemekle kalmayıp, aynı hissettirdikleri ve deneyimler için benzer olanaklar sundukları noktalara kadar zayıflamasıdır. Bayağılığını (kitsch) ve tekniğini yayarak; önemli yerler yaratmak ve sürdürmek için neredeyse hiçbir şey yapmayan süreçler ve medya aracılığıyla yayılmaktadır. Bu süreçler ise; kitle iletişim araçları, popüler kültür, büyük şirketler, güçlü merkezi otorite ve tüm bunları kucaklayan ekonomik sistemdir (Relph, 1976, 79-87). Yersizlik, hem yerlerin fiziksel anlamda birbirlerine benzeşmesini hem de farkl1 yerlerin aynı deneyimleri barındırmasını kapsamaktadır. Yani yersizlik, hem mekânsal hem de ruhsaldır, aynılaşma ve monotonlaşmayı beraberinde getirmektedir. Aynılaşan yerler, bireyler için bir 'anlam' taşımamaya başlamakta, benzerlikler denizi içinde kaybolma hissi yaratmaktadir.

Yer tartışmaları ve tanımlarında olduğu gibi yer-sizlik için de farklı görüşler bulunmaktadır. Augé ‘ye göre mekân ilişkisel, tarihsel ve kimlikli olmalıdır. Küreselleşmeyle birlikte tarihsellik ve bir kimliğe ait olma özelliği azalan veya yok olan mekânlar ortaya çıkmıştır. $\mathrm{Bu}$ özellikleri taşımayan bir yer, yer-olmayan/ yok-yer (non-lieu) olarak tanımlanmaktadır (Uzunkaya,2014, s.33).

Heidegger, Schulz ve Relph gibi düşünürler fenomenolojik yaklaşımla yersizlik tartışmalarını sürdürürken; Deleuze ve Guattari gibi düşünürler Heidegger'in varoluş felsefesinin yerine 'oluş'a önem vermekte "yersizyurtsuzlaşma (detteritorialization)" kavramını ortaya koymaktadırlar. Deleuze yersizleşmenin karşısında durmamakta, yersizleşmenin yeni toplumsal yapılanmalar sağlaması için etkin kullanılması gerektiğini vurgulamaktadır (Koçyiğit, 2007, s.127-129). 


\section{Yer(leşme)/Yersiz(leşme)nin Kavramsal Bileşenleri ve Ahlat A $\breve{g} a c \imath$ üzerinden okunması}

\section{Mekansal: Eylemlerin Gerçekleştiği Alan}

Eylemlerin gerçekleştiği alanlar üç boyutta bir hacim olarak değerlendirilmekte ve "içinde", "dışında", "karşısında" vb. olunabilecek "mekânlara işaret etmektedir. Kimi zaman kapsayıcı, kimi zaman dışlayıcı kimi zaman ise bağlayıcı olabilmektedirler (Norberg-Schulz, 1980, s.16).

Konum (içinde/dıșında/karșısında ...): Ahlat Ağacı'nda sinırlılıklar; Sinan'ın gözünden, bulunduğu konuma göre beş sahneye karşılık gelecek şekilde ayrılmıştır: Barınak (sahne-1), kırsal (sahne-2), kasaba (sahne-3), şehir (sahne-4), köy (sahne-5).

'İçinde' bulunulan konum olarak barınak, sahne 1'i kapsamaktadır. Bir barınak olarak işlevlenen mekanlar Sinan ve ailesinin paylaştığı ev ile İdris'in kendine köyünde inşa ettiği evidir. En temelde, bir mekanda bulunduğumuzda içeride ve dışarıda ayrımı bizi konumlandırır. Her insan için kendi barınağının en 'içeride' olduğu yer olduğu söylenebilir.

Kapsayıcılık/dışlayıcılık: Hatice ile karşılaşılan ve doğayı çerçeveleyen sahne 2 ise konum olarak kır-salı karşılamaktadır. Sahnedeki insan yapımı tek şey Hatice'nin su almaya geldiği çeşmedir. Diyalog da bu çeşmenin başında sürmektedir. Doğanın 'içinde' iki insan oldukça yapay durmakta, kendi benliği ile en iyi şekilde 'yer' olan, biricik olan doğa adeta bu iki insanı dişarı kusmakta, dışlamaktadır. 'Modern' insan doğaya o kadar uzaklaşmıştır ki doğa bu iki insan için yalnızca bir manzara sunmaktadır. Öyleyse eylemlerin gerçekleştiği alan olarak yer bir arka plan olmaktan öteye geçemiyorsa, dokunulmuyor, hissedilmiyorsa ruhunu yaşatabiliyor mudur? Her şeye rağmen doğa Ceylan'ın gözünden gördüğümüz ve dikkat çekildiğimiz üzere; estirdiği rüzgarıyla, ışık hüzmeleriyle, hışırdayan yapraklarıyla ruhunu 'insana' sarmalamaya çalışmaktadır.

Eylemlerin gerçekleştiği alan bağlamında yer tanımlayıcıdır. Ayrıca bununla ilintili olarak günlük yaşantıda her eylem için farklı bir alana ihtiyaç duyulması, yerlerin işlevlere göre de farklılaşmasını beraberinde getirmektedir. Yemek yeme gibi temel işlevlere hizmet eden mekânlar bile kültürel farklılıklara göre çeşitlilik göstermelidir. Bu yüzden işlevsel yaklaşımı eleştiren Farklı kültürel geleneklere ve farklı çevre koşullarına uygun olarak farklı özelliklere sahip mekânlar gerekmektedir, bu nedenle işlevsellik öznel ve karakteristik özellikleri dışlamaktadır (Norberg-Schulz,1980, s.16-17).

İşlevsel ve kültürel farklılaşma: Eylemlerin gerçekleştiği alan olarak köy, sahne 5'i kapsamaktadır. Sahne 5 boyunca köyü izlemekte ve karakterler ile birlikte köyde gezmekteyiz. Sinan'ın bıraktığı köy kendi yaşam biçimi doğrultusunda sürüp gitmekte, kendi temposunu korumaktadır. Bu anlamda köyün kültürel farklılıkları doğrultusunda, belki de doğanın ritmi ile süren bir yaşamın sonucu olarak eylemlerin gerçekleştiği alanını özelleştirdiği ve kısmen yer olma özelliğini sağladığı söylenebilir.

Dünyadaki konumumuzla ilgili algımıza, bulunduğumuz yere giderken yaptığımız şeyler, gördüğümüz, duyduğumuz ve hissettiğimiz her şey katkıda bulunur. Bulunulan yer de anıları ve bilgiyi harekete geçirir ki bu da belleğimizin nerede bulunduğumuzu anlamamız için bize yardımcı olma şeklidir (Groh, 2021, s.17). Eylemlerin gerçekleştiği alanlar yani mekanlar aynı zamanda anı oluşumuna sahne olan ve depolanıp bir arşiv görevi gördüğü alanlardır (Groh, 2021, s.183). Eylemlerin gerçekleştiği alan, yerin mekânsal özelliklerini karşılamasının yanı sıra belleğimizde yer edinmiş her türlü ant, imge, simge vb. üç boyutlu sınırları çizen ve işlevlerin özelleşmesinin önünü açan gör-sel sınırlılıklar bütünüdür.

Anı, bilgi, bellek, arşiv oluşturma : Groh'un vurguladığ üzere bellek olağan ve otomatik eylemlere nüfuz etmiştir. Ama bu özelliğiyle mekânsal olan belleğin, yer olma özelliğine 
katılması anıların depolandığı ve ortaya çıkarıldığı noktada başlamaktadır. Sinan, kentten (sahne-4) kasabasına (sahne-3) döndüğünde veya askere gidip geldiğinde -her ne kadar iki mekân da eylemlerini gerçekleştirdiği alan olsa da- anılarına sahne olan yer anlamsal dönüşümler gerçekleşmiştir. Kasabaların modern kent yaşantısına öykünmesiyle kentleşmeye başlamasının da etkisiyle dönülen kasabada her şey değişmiştir. Bu değişim yalnızca fiziksel anlamda bir değişim değildir. Sinan'ın dönüp kasabasına baktığı sahnede oluşan muğlaklaşma hissi, belleğinde yer eden ve Sinan'ın için bir arşiv oluşturarak aşinalık yaratan yerlerin ruhlarının da muğlaklaştığını göstermektedir. Bu muğlaklaşma, ruhun yitimine bir örnek oluşturmakta yersizliğin en kuvvetli göstergelerinden olan mekanların içlerinin boşalması ve anlam kaymasına bir gösterge sunmaktadır. Sinan'ın arkasında gördügüümüz, kendinin de tanımaya çalışırcasına dönüp baktığı kasaba neresi, kimin kasabasıdır? Sinan'ın kasabası ile herhangi bir şehir arasından fark var mıdır veya kalmış mıdır? Beton bloklar, toprak, fabrika bacalarının dumanları...

Sinan'ın üniversite okuduğu, mesleğini eline aldığı şehir de daha sonra geri dönüp mesleğini yapabilmek için sınava girdiği şehir (sahne-4) de aynıdır aslında. Sinan'ın sınava girerek, çay bahçesinde oturulup çay içerek, bir arkadaşla laflayarak anı oluşturduğu mekân, kendi içinde farklı yerleri barındırsa da bir hacim olarak tektir. Ancak bu yerler zaman içinde fiziksel olmasa bile anlamsal dönüşümler geçirmişlerdir. Filmin içinde kare kare gezdiğimiz bu mekanlarda Sinan üzerinde yaratılmış bir aidiyet ararız ama daha önce burada bulunmuş olduğunu anlamamız dışında bir türlü bir aşinalık bulamayız. Sinan'ın bulunduğu konum ve mekan olarak şehirde hiçliğe doğru uzanan yolculuğuna tanık oluruz.

\section{Ruhsal: Kimlik, Karakter, Varlık}

Karakter, bir şeylerin 'nasıl' olduğuyla ilgilidir ve gündelik hayatımızın somut fenomenlerini araştırmak için temel oluşturur. Ve ancak bu şekilde, antik toplumlarda "yerin ruhu" olarak tanımlanan şeyi anlayabiliriz. Karakter "sıfatlar" ile tanımlanır. Bir karakter karmaşık bir bütündür ve tek bir sıfat bu karmaşık bütünü kapsayamaz (Norberg-Schulz, 1980, s.17).

Sıfatlar kümesi: İlhami ile olan diyalogta (Diyalog 3), Sinan ısrarla kitabının yaşam kültürü üzerine olduğunu anlatmaya çalışmakta İlhami'den bir tepki beklemektedir. Yerin kimliği, içinde yaşayanlar için ne denli önemli ne denli farkındalık yaratacak düzeydedir? Mekânsal yani somut özellikleriyle bir yer bir kimlik oluşturmakta aslında toplum üzerinde her 'yer' belirli bazı imgeler ile kimlikleşmektedir. İlhami'nin de Sinan'ın kitabını çevreyi tanıtıcı özellikte olduğunu düşünmesinin temel sebebi budur. Halbuki bir yer imgeler bütününden öte toplumsal özellikleriyle de bir kimlik oluşturmakta içinde yaşayanlar ile birlikte var olmaktadır. "...Yani mesela çarşının ortasında, fötr şapkasıyla şarap içip meyve satan yaşlı bir dede var mesela..." diye anlatmaya çalışarak kentlinin de bölgenin ruhuna anlam kattığını vurgulamakta ama bu İlhami için bir şey ifade etmemektedir. Yani toplumsal varlıklar olan insanlar kendi hayatlarını, tarihlerini, bilinçlerini, dünyalarını üretirler (Lefebvre, 2014).

Sinan üniversiteyi oşehirde okuyarak, deniz kıyısında bir çay içerek, yollarında yürüyerek o şehirle ilgili kendi bireysel anlamını oluşturmuştur. Kendi bireysel anlamını oluştururken kendi kimliğine eklemlenmiş bu anlamı o yere eklemiş o yerin kimliğine kendinden bir anlam kazandırmıştır. Sinan da "Olgulamalar değil yorumlamalar vardır..." diye vurgulayarak (diyalog-4) bunu anlatmaya çalışmakta İlhami ile olan diyaloğuna benzer olarak Süleyman'a da yerin kendi için oluşturduğu anlamı anlatmaya çalışmaktadır. Yani bir yerin kimliği nasıl yalnızca o yere özgü görsel imajlar kolajı değilse o yeri "tanıtıcı" bir şeyler yazıyor olmak da kalıplaşmış, yüzeysel tanımlamalarla yapılamayacaktır.

Temelde bakıldığında, karakter bir şeylerin somut olarak ve/ veya soyut, tinsel anlamda neye karşılık geldiğini tanımlamaktadır. Bu tanımlama ise ayırt edici bir özellik 
barındırmaktadır. Basit tanımla, "şey"lerin, "şey"lerden ayrılmasını sağlar. NorbergSchulz' un da sıfatlarla tanımlandığını vurguladığı üzere bir "şey" in karakteri o şeyi oluşturan sıfatların kümesini oluşturmaktadır. Relph (1976, s. 45-46) ise, kimlik (identity of) kavramını; bir şeyin diğerlerinden ayırt edilmesini sağlayan bütünlük ve sürekli bir benzerlik olarak açıklamaktadır. Yerlerin kalıcı kimliğini (identity of place) 3 bileşen olarak tanımlamaktadır; (i) mekânın fiziksel ortamı, (ii) Faaliyetleri, durumları, olayları ve (iii) o yerler ilgili insanların deneyimleri ve yaratılan bireysel anlam. Karakter kavramı o "yer" ile ilgili sıfatların bir araya gelmesiyle tanımlanabilirken, kimlik de buna paralel olarak Relph' in tanımladığı üç ana bileşen ile ele alınabilir.

Soyut/somut karşılık: Bütün köyü dolaşarak süren diyalogta (diyalog-5) bir noktada konu yeni yapılacak camiiye gelince Sinan "büyük büyük camlar, kubbeler, otomatik kapılar..." hayal etmekte, bir yandan da kendi eleştirel bakışını oluşturmaktadır. İbadet eyleminin gerçekleşeceği 'camii'ler de birbirlerine benzemekte, yere ait özelliklerini yitirmekte ve muğlaklaşmaktadır. İşlevsel anlamda bekleneni sağliyor olarak görünse de yerler anlamsal bütünlüğe ulaşmadıklarında; uzayda bir boşluk tanımlayan mekânlardan öteye geçememektedirler. Karakterler ve kamera köyde gezerken bir yandan da düşünceler mekânsal pratiklerin anlamı üzerinde gezmektedir. Sinan'ın kafasındaki ibadet mekanı somut özellikleriyle yalnızca bir tipoloji oluşturmakta; herhangi bir deneyime dayanmayarak, içinde herhangi bir yaşanmışlık barındırmayarak kimliksizleşmekte ve yersizleşmektedir.

Somut özelliklerin ötesinde; kimlik kavramını, yerin kimliği (identity of place) kavramına dönüştürecek özellikler vardır. İçinde yaşanıldıkça, paylaşıldıkça ve çoğaltıldıkça yer kimlik kazanmaktadir.

Yașanılan, paylașılan, çoğaltılan: Sinan kendini, bir başka insanın -İdris'in- oluşunu sonlandırdığı yer'de bulmuştur. Bu noktada iki insanın oluşları çarpışmaktadır. Aralarında geçen diyalog'ta (diyalog-1) da görüldüğü üzere Sinan arayışını sürdürmektedir:

Sinan: Ne bileyim. Ya senin gibi doğu göreviyle gençliğimizi yiyeceğiz ya da işte buralarda alakasız bir işe girip gene gençliği yakacağız. Sence ne yapayım?

Basit bir sorgulayış-teslimiyet gerginliği olarak da görülebilir fakat, aslında yerin kimliği (identity of place) ile insanın kimliğinin (identity of) görünmez iplerle birbirine bağlı olduğunun göstergesidir bu arayış. Sinan, o yerde ol-mak ve ol-mamak ile de kendini dönüştüreceğini, yerin yaşanılan ve paylaşılan olma özelliğininin insanın kaderi ve karakteri ile doğrudan ilgili olduğunu vurgulamakta ve eleştirmektedir. Yerin karakteri, insanın ve/veya toplumun kendi ihtiyaç ve isteklerine göre özelleşmiş durumları barındırmadığı noktada ruhunu kaybetmeye başlamaktadır. Yalnızca gündelik hayat rutinlerinin benzerliklerinin kimliklendirdiği yerlerin insanları, Sinan'ın bezelye benzetmesine paralel olarak birbirinin aynısı robotlardan oluşan bir toplumun ötesine geçememektedir.

Sinan: Seni de, kendimi de bazen dedemi bile bu Ahlat Ă̆acı'na benzettiğim oluyor bazen. Ne bileyim böyle uyumsuz, yalnız, şekilsiz.

İdris bulunduğu kasabadan, yalnızca görev dolayısıyla ayrılmış ve emekli olunca da köyüne yerleşmiş bir karakterdir. Sinan da hem İdris $>$ hem de dedesini ve hatta kendisini de birbirine benzetmekte; bu benzerliğin ortak noktasını ve temelini de bulunulan 〈yer〉 oluşturmaktadır. Yer, bir ruh kazanırken sakinlerinin ruhunu da kendi ruhuna katmaktadır.

Deneyim yoluyla kavrama: Sinan için, uzun zaman sonra gittiği köyü anlamin ve deneyimlerin silinmeye başladığı bir yer haline gelmiştir. Hatice ise hala o anlamin içinde yaşamaktadır. Yani bir yerde bulunmak ve bulunmamakla, daha önce bulunmuş olmakla o yere bir anlam, bir ruh atfederiz. Kimi zaman bu ruh, tıpkı Hatice'ye olduğu gibi insanı bir kafese kapatılmış hissine sebep olurken kimi zaman da Sinan'a olduğu gibi ruhun yitimine sebep olmaktadır. 
Sinan: Sevmiyorum buraları. Dar kafal, hoşgörüsüz. Bezelye taneleri gibi birbirine benzeyen bir sürü insan. Burada ömür çürütmeye niyetim yok diyerek (diyalog 2) aslında geride bıraktığ 1 bu yer hakkında sıraladığı sıfatlar ve tanımlar ile bir kimlik oluşturmakta; içinde bulunan insanların ne denli birbirlerine benzediklerine dikkat çekerek yerin ve toplumun kimliğinin nasıl da birbiri ile bağlantılı olduğunu vurgulamaktadır. Yerin somut sinırlılıklarının yanı sıra; yaşanılan, paylaşılan ve toplum aracılığıyla çoğaltılan ve bu sayede deneyim oluşturan soyut sinırlılıkları bulunmaktadır. Yere ruhunu kazandıran özellikler arasında bulunan bu sinırlılıklar toplumla birlikte oluşurken bir yandan da toplumu içine çekerek yaşam pratiklerinin sınırlarını çizmektedir.

Heiddeger'e göre yeryüzü, düz ve mecazi anlamiyla varoluş yeridir (Sharr, 2010, s.45).

“... Heidegger'e göre toprak İnsanlar yerleştirir [situate]..." (Sharr, 2010, s.45).

Yaşanılan hacim-ler, insanın var-olma arzusu ile yaratılmaktadır. Ama aynı zamanda da insanın varlığına hizmet etmek için kullanılırlar. (Heidegger insana hizmet eden 'şey'leri alet olarak görmekte ve varlığa hizmet eden 'şeyler' olarak işlemektedir.) Varlık ve yer ilişkisi bu ilkel ama bir o kadar da temel sava göre değerlendirilecektir. Heidegger'e göre mekânlar, matematiksel olarak kavranan "mekân"la değil, insan deneyimi yoluyla kavranan "yer"le varlık bulur (Sharr, 2010, s.53).

Heidegger'e göre, farklı varoluşlar içinde de, iki farklı varoluş biçimi vardır: gündelik hayatta ve sıradan oluş içinde insanın durumu gibi kitle içinde saklanan, kaybolan varoluşça ve kendi gerçekliğinde ve kendine özgü oluş içinde yaşayan varoluşça. Kitle; onlar ve hiç kimsedir, yani kamusal (publikum) ve kolektiftir. Kitle içinden kopuk yaşayan insan ise kendi gerçekliğini oluşturur (Ergül,2003, s.70). İnsanın varoluşu dünyada olmak ile başlar, fakat yalnızca dünyada gerçekleşmez aynı zamanda insan, diğer insanlar ile vardır. Yani, varlık aynı zamanda toplumsaldır.

Toplumsal-bireysel varoluşça: Sinan'ın olduğu gibi İdris'in de varoluşu diğerleriyle birlikte olmak üzerine kurulamamakta; kendi başına kendi dünyasında var olmasıyla kurulmaktadır. Hatta İdris bir adım öteye geçerek kendi yaşam alanını köyde yaratmış ve yaratmaktadır. Kendine bir ev yaratmakta, kuyudan çıkaracağı su ümidiyle yaşamını ve varlığını sürdürmektedir. Sinan' $1 n$ Hatice olan diyaloğunda (diyalog 2) ise Sinan' in bazı reddedişler ve arayışlar içinde olduğunu; Hatice'nin ise derin bir sorgulayış içinde olduğunu görmekteyiz. Sinan için içinde bulunduğu toplumla varolmayı (birlikte varlık) reddetmektedir: "Sevmiyorum buraları. Dar kafalı, hoşgörüsüz. Bezelye taneleri gibi birbirine benzeyen bir sürü insan. Burada ömür çürütmeye niyetim yok. " Hatice kendini bulunduğu yerde var edememiş gelecekte bulunacağ1 yerlerde de var edebileceğine inanmamaktadır: "Sana tuhaf gelebilir belki ama; insan neden önünde duran hayatı seçip onu yaşamak zorunda ki?"

Aslında, Sinan bulunduğu bütün yerlerde olmakla veya geçmişte bulunmuş olmakla orada bir var-lık oluşturmuştur. Üniversiteyi okuduğu şehirde; içtiği çay, okuduğu kitap, yürüdüğ ü yol; kasabasında kaldığı ev, kitabını bastırmak için gezdiği mekânlar bir yer'e aittir. O yerlerde Sinan'ın bulunmuş olması o yerleri etkilemiş, dönüştürmüştür. Bağlantılı olarak bu yerler de Sinan'ı dönüştürmektedir. Fakat bu dönüşüm Sinan'ın ruhunu yaşatabileceği bir yer edindiği anlamına gelememiştir. Yani denebilir ki, Sinan bu iki varoluş arasındaki gerilimde yaşamaktadır. Kitle içinde kaybolan varoluşu reddetmekte (toplumsal varoluşça), kendi gerçekliğinde (bireysel varoluşça) yaşadığı için de bir türlü yaşama tutunamamaktadır. Burada bahsedilen var-olamama durumu bulundukları yerlerin ruhunun kendi ruhlariyla buluşmamasından kaynaklanmaktadır. Bir başka deyişle, yerin ruhu insanın ruhundan bağımsız olamayacağından bir var-lık/ var-olma sorgulaması söz konusu olduğunda tüm değerlendirmeler tüm bu bileşenleri kapsayıcı ele alınmalıdır.

Çağlar boyunca insanın ve yerin kimliğinin oluşumu birbirini doğrudan etkilemiştir. Yani, bir başka deyişle ruh ve yerin ruhu karşılıklı dönüşüm içindedir. Elbette bu dönüşüm 
karakterin ve kimliğin değişimi anlamında değildir. Fakat bu birbirini tetikleyici dönüşümler kimliğin oluşumunu etkilemektedir. Bu, 'oluş' hali noktasal ve anlık değil; çizgisel ve hatta ışınsaldır. Sinan'ın da film boyunca kimliği bir oluş halindedir. Bulunduğu mekânlar (Kasabası, üniversiteyi okuduğu şehir, film boyunca bir dolaşım halinde bulunduğu mekânlar) bu oluş halinin arayışlarını oluşturmaktadır. Yazdığı kitabını yayınlatmak için bir uğraş halinde bulunduğu tüm olaylar aynı zamanda, aslında kendisi için bir arayışı işaret etmektedir. $\mathrm{Bu}$ arayış Sahne-1'in ilk saniyelerinden Sahne-5' in son saniyelerine kadar devam etmektedir.

\section{Mekansal\&Ruhsal: Bölge, Yöre, Ev}

Bir 'yer' olarak; bölge, yöre betimlenirken birincil olarak doğal ve insan yapımı olarak ayrılmaktadır. Bu noktada, kırsalın (yerleşim bölgesi anlamında kasaba da denilebilir) yöre, iklim ve doğa ile bağının çağdaş şehirlerden çok daha güçlü olduğu söylenebilir. NorbergSchulz da, doğal ve insan yapımı yani daha somut tanımla peyzaj ve yerleşim yeri arasındaki ayrıma dikkat çekmektedir. Norberg-Schulz'a (1980, s. 50) göre insan yapımı yerler mevcudiyetlerini 'sınırlardan' alır, yerlerin varlıkları sınırlar ile başlar. Mekânsal yapılar mimarlık tarihi boyunca kendini, merkezileşme (centralization) ve dikeyleşme (longitudinality) olarak sınırlandırmıştır. Genel anlamda bu şekilde sınırlanan mekânsal yapılar; iç mekân iseler döşemelerle; dış mekân iseler gökyüzü ile sınırlanırlar.

DoğaV insan yapımı: Temelde insan yapımı ve doğal olarak ayrılan bölgenin çıkış noktası öncelikle coğrafi özellikler bağlamında şekillenmektedir. Lefebvre'nin (2014, s.97) vurguladığı üzere doğanın yaratımı her şey biriciktir. İnsan yapımı yerlerin doğaya öykünmesi de bir bakıma biricik yerler üretme çabası olduğu söylenebilir. Bu noktadan bakıldığında sahne 1'de bulunan iki barınakta dikkat çekici bir ayrım bulunmaktadır. Biri şehrin içinde kaybolmuş, doğadan tamamen kopmuş hiçliğin, bağlamsızlığın içinde süzülmekte olan ve barındırdığı insanlara da sundukları köksüzleşmeye başlamış bir mekan; diğeri ise doğaya tutunmaya çalışarak kendi bağlamını ve anlamını oluşturmaya çalışan bir yer. İdris, Sinan'ın ruhunu yitirmeye başlayan barınağından kaçışını ruhunu yaşatabileceği kendi barınağına doğru yapmıştır. Bu noktadan bakıldığında ruhun yitimi, devamında gelen yeniden yer yaratma ve doğaya tutunma güdüsüyle yersizyurtsuzlaşma peşinden gelen yeniden yurtlulaşmaya benzeşiyor denebilir.

Kirsal-Kentsel: Sahne 5 boyunca köyü izlemekte ve karakterler ile birlikte köyde gezmekteyiz. Sinan'ın biraktığı köy kendi yaşam biçimi doğrultusunda sürüp gitmekte, kendi temposunu korumaktadır. Burada dikkat çekici olan nokta yerin ruhunu kaybetmediği halde Sinan için o ruhun kaybolmuş olduğudur. İdris ise kendi dinamiklerini köye uydurmuş ve o yerin ruhuna katılmıştır. Ancak bu yer için diğer bir dikkat çekici nokta ise aslında özelliklerinden belirli noktalarda tavizler vermeye başladığ1, bazı noktalardan yersizleşmeye doğru gittiğidir. Bu noktayı da yine Sinan, camii inşaatını "büyük büyük camlar, kubbeler, otomatik kapılar..." tanımlamaları (diyalog 5) ile eleştirerek ipucu vermektedir. Bu kırsal alanda yapılmakta olan camii bölgesel özelliklerine ne kadar uymaktadır? Bir ibadet mekânı her küçük topluluk için bazı bölgesel özelleşmeler içermelidir. Yerin yer olabilmesi için bu bölgesel özellikler somutlaştırılmalıdır ve işler hale gelebilmelidir.

İnsan yapımı yerler, doğayla; gördüğ ünü taklit etme, eksik olanı tamamlama ve doğayı sembolize etme olarak üç yolla bağlantı kurmaktadır (Norberg-Schulzıa (1980, s. 17) Doğanın yarattığı her 'şey' biricik olan birer yapıttır. Doğa yaratır, üretmez; insan, yani toplumsal pratik ise yapitlar yaratır ve şeyler üretir (Lefebvre, 2014, s.97).

Yaratılmışlık/Üretilmişlik: Ceylan, doğal ve insan yapımı ayrımını filmde çok net ve açık bir şekilde yapmaktadır. Ceylan, Sahne-2'de doğalı, doğayı oldukça derinden hissettirmesine rağmen doğanın içindeki iki insan yerden tamamen kopuk bir ilişki içinde bulunmakta; diyalog (diyalog 2) da bu gerilimli ilişkiyi desteklemektedir.Kırsalın içinde yaşamına devam eden Hatice, şehri ve şehir yaşantısını farklı hayal etmektedir. 
“...Hatice: Ne bileyim. Kalabalık ışıklı caddeler, rüzgarlı tepeler, güzel yemekler. Sinan: Hepsini gördük, bir numara yok hiçbirinde. Başka..?"

Yartılmış doğa, Hatice için potansiyelsiz ve bağlamsızlık anlamına gelirken insan üretimi şehirler heyecan ve merak uyandırmaktadır. Kalabalık, ışıklı caddeler Hatice için bir hayalken Sinan için kaçıp kurtulmak gereken bir durumdur. Yani, bölgenin/ yerin özellikleri ve potansiyelleri kullanıcıları için bambaşka anlamlar barındırmaktadır.

İnsan, var-lığını somutlaştırabilmek için toprağı işlemeye başladığında kendi barınağını da yaratmaya başlar. Yani, denebilir ki varlık «ev`e dönüşerek gerçeklik kazanmaya başlar.

“...Barınan varlık, barınă̆̆nın sınırların diyalektiklerin en bitip tükenmezi içinde duyarlaştırır. Evi gerçekliği içinde; düşünceleriyle ve düşleriyle de sanallığı içinde yaşar." (Bachelard, 1996, s.33).

Ev, bizim ilk evrenimiz, kozmosumuzdur (Bachelard, 1996, s.32). Bu kozmos, içinde barınılan bir yer iken bir yandan da dış dünyaya karşı sergilenen tavrı da şekillendiren bilinçsiz bir edinimdir. Ev, her birey için ayrı ayrı birer kozmostur. Ev, aidiyet kavramını da beraberinde getirmekte ve bir mekân olmaktan öte var-olunan hacim haline dönüşmektedir. Ev, insan varoluşunun derin merkezleridir. Ev yalnızca bir ev değil yuva, yeri doldurulamaz bir anlam merkezi ve bir topluluğun bireyleri ve üyeleri olarak kimliğimizin temelidir (Relph,1976).

Kozmos oluşturma: Şehrinden ayrilıp kasabasına dönerken Sinan'ın evine (sahne-1) döndüğünü varsaymaktayız. Fakat, Sinan için -neredeyse bütün film boyunca olduğu gibidaha ilk sahnelerden dönüşün ne denli huzursuz olduğu yansitılmaktadır. Sinan, köyü ve kasabasından ayrılıp şehre geldiğinde kendine burada yeni bir yaşam inşa eder. Bu yaşam içinde şehrinde kendine bir ev yaratır. Burada barınır, okur, paylaşır ve deneyimler. Bu yüzden, sahne 4 boyunca gördüğümüz yerler Sinan için ev diye nitelendirebileceğimiz yerlere en yakın yerlerdir. Ancak yine de Sinan için net bir ev işaretleyememekteyiz. Belki de filmde bu denli bir mekânsal gerginliğe sebebiyet veren şey Sinan'ın ev'sizliğidir. Fiziki anlamda bir evsizlik söz konusu değildir. Fakat Sinan, yaşadığı bu ruhsal gelgitler içinde, dünyada kendine bir yer aramaktadır aslında. Her evin içinde yaşayanlara göre ve eylemlerine, günlük rutinlerinde göre özelleşmiş alanları bulunmaktadır.

Evi barınaktan öteye geçiren temel farklılaşmalar da bunlara dayanmaktadır. Temelde 'barınma' eylemi için üretildiği düşünülse de ev, içindeki eylemlerin anlamlı bütünlüğü içinde bir yer, bir yuva haline gelmektedir. Sinan, var-olunan hacim olarak tanımlayabileceği bir eve, bir 'yer'e sahip değildir. Film boyunca Sinan'ı evinde yalnızca parça parça görmekteyiz Sinan evi bir durak noktası olarak kullanmaktadır. Ayrıca Sahne-1'in parçalarından birinde Sinan'1, İdris'in yeni evinde/yerinde görmekteyiz. İdris'in bu yer'ine aitliği Sinan'1 şaşırtmakta ve sarsmaktadır. Bir hacim, insanla var-olmakta, insanla birlikte yer'e dönüşmektedir. İdris'in yıllarca bir düzen oturtamamasına rağmen bu yerde var-olabilmesi Sinan'a mucizevi gelmektedir. Yani, bir mekân bütün özellikleriyle, bir öznede, yer iken aynı zamanda bir çizgide; başka bir öznede (belki de nesnede), yersizleşmeye başlamış bir hacimden ibaret olabilir.

"Yer deneyimleri ve özellikle ev deneyimleri, kaçma arzusu ile kalma ve ait olma erdemleri arasinda bir tür diyalektik dengedir." (Relph,1976,s.42)

Kaçma/kalma arasındaki diyalektik denge: Sinan'ın kendi kozmosunu aradığ1 film boyunca diğer karakterlerle karşılaşmalarında da sürekli bir sorgulayış görmekteyiz.

Sinan: Ne bileyim. Ya senin gibi doğu göreviyle gençliğimizi yiyeceğiz ya da işte buralarda alakasız bir işe girip gene gençliği yakacă̆ız. Sence ne yapayım?

Diyalog 1'de Sinan'ın sorguladığı üzere kaçma ve kalma yani o yerde olmak ve olmama Sinan'ın en büyük arayışını tanımlamaktadır. Sinan, Hatice ile karşılaştığında, ikilinin diyaloğunda bu sefer de Hatice'nin arayışıyla karşılaşırız. Hatice'ye göre içinde yaşadığı yer 
tamamen ruhunu kaybetmiş veya hiçbir zaman Hatice' nin ruhuyla buluşamamıştır. 'Ev'lenmek üzere olan Hatice, kendi evini bulamamışken başka bir yerde ruhunu yaşatabilecek mi diye sorgulamakta bir yandan da hiç gidip görmediği yerler ile ilgili hayaller kurmaktadır:

\section{“...Uzaklara giden gemiler, ılık akşamlar, aşklar, sarhoşluklar, yağmurun altında islanmalar..."}

Hatice aslında farkında olmadan, o 'yer'de yaşayabileceği deneyimlerin hayalini kurmaktadır. Bu deneyimler yaşandıkça insan kendini o yerde ait hissetmeye başlamaktadır. Bir yerin eve dönüşebilmesinde de en önemli unsurlardan birinin ait olma duygusu olduğu söylenebilir.

\section{Sonuç}

İnsan her ne kadar kendi başına dünyada varlığını sürdürüyor olsa da temelde başka insanlar ile yani bir toplum olarak var-olmaktadır. Lefebvre (2014, s.67-68) mekânı üçlü diyalektik süreç olarak açıklamaktadır. Bu süreçleri; (i) maddi mekânsal pratikler (algılanan mekân, mekân temsilleri), (ii) tasarlanan mekân (hayal edilen) ve (iii) temsil mekânları (yaşanan mekân) olarak tanımlamaktadır. Lefebvre'e göre mekân diyalektik olarak bağlı bu üç boyutuyla 'toplumsal' bir üretimdir. Lefebvre'in (2014, s.95) de vurguladiğ1 üzere; kendi hayatlarını, tarihlerini, bilinçlerini, dünyalarını üreten insan toplumsal bir varlıktır ve toplumda her şey edinilmiş ve üretilmiştir. İnsan, başka bir insan «ile» olmaya başladığ noktada bir «kitle» haline gelmekte ve bireysel ruh, toplumsal ruha karışmaya başlamakta ve hatta kolektif bir ruh ortaya koymaktadır. Dolayısıyla, varlık ve ruh, toplumsal olandan ayrı düşünülememektedir. Toplumsal bir varlık olan bireyin (insanın) bireysel ruhu, diğer bireylere bulaşarak, etkileşime girerek toplumsal ruha dönüşmektedir. Bu toplumsal ruh bulundukları 'yer'leri etkilemekte; bir zaman sonra ise yerin kendi ruhu oluşmaktadır. Yani 'bir' ile başlayan varlık bütünsel bir varlığa dönüşmektedir. Fakat; bir süre sonra yerin ruhu, çalışma boyunca incelenen sebeplerle oluşumundan bağımsız bir noktaya ulaşmaktadır. Özellikle de bu dönüşüm her şeyin tek tipleşmeye başladığı, yersizliğe doğru gitmeye başladığı noktada gerçekleşmektedir. Yersizleşmeye başlayan bu çevre içinde kendini arayan Sinan'in, İdris'in tek tipleşmenin dışında kalan küçük dünyasına geldiğinde bir duvara çarpmış gibi olmasının esas sebebi budur. Ruhunu yitirmiş yerler içinde bir kuyuyla ve ahlat ağaciyla yere bağlanan İdris'in hayatı Sinan'ı sarsar. Umudunu yitirip kendini kuyudan sarkıttığını gördügüümüzde Sinan' in da ruhunu yitirdiğini düşünürüz. Gerçekte, Sinan da İdris`in kozmosu içinde ruhunu aramaya karar vermiştir.

Filmin genel ruhuna ve Sinan'ın ruh haline hakim olan karamsarlık, depresif hal bulunulan yere uzaklaşma ve beraberinde soyutlanmayı da getirmektedir. Amaçsız ve yaşama sebebini yitirmiş bir karakter olan Sinan aidiyetlerini yitirmiş, yabancılaşmış ve modern kent insanının bıkkın ruh haline bürünmüştür (Demir, 2020, s. 76). Demir (2020, s.77) çalışmasında, Simmel'in (2009, s. 321) aksine bıkkınlığ1 (bezmişliği) mekana koşut olarak görmese de, ruh yitiminin sonuçları olarak değerlendirilebilecek bezmişlik durumu, çalışmada tartışıldığı ve üzere Simmel'in $(2009$, s. 321) vurguladığı üzere; metropolün sonucu ve mekânsal bir 'problem'dir ve 'yersizlik' ile ilgilidir. Film boyunca ana karakter Sinan üzerinden farklı yersizleşme noktalarını, bezgin farklı karakterler aracılığıyla gezmekteyiz. Sahne 1'de barınağın nasıl yersizleştiğini ve diyalog 1'de de İdris (baba) aracilığıya bu yersizliğin nasıl ruhun yitimine dönüştügünü görmekteyiz. Benzer şekillerde ama farklı sebeplerle sahne 2' de kırsalı, sahne 3'te kasabayı, sahne 4'te şehri ve sahne 5'te de köyü yitirişimizi izlemekteyiz. Ceylan, karakterlerle Sinan'1 sahnelerde karşılaştırarak; o yerin nasıl deneyimsizleştiğini; yaşanılan, paylaşılan olamadığını ve anıları biricikleştirerek çoğaltamadığını gözler önüne sermektedir. Çalışma boyunca bütün bu yoksunluklar 'ruhun yitimi' olarak okunmaktadır. Sinan'ın umutsuz, sürekli bir arayış içinde olma halinin sebebi de bulunduğu, bulunmayı hayal ettiği bütün yerlerin yersizleşmeye başlaması ve ruhunu yitirmesi olduğu söylenebilir. 
Hatta öyle ki yalnızca Sinan' ın değil İdris' in, Hatice' nin ve hatta Süleyman'ın da 'bulundukları' yerden kaynaklanan ve diyaloglara da sirayet eden bu kaybolma hali, ancak yaşadıkları mekanların gerçek bir "yer"e dönüşmesi ile yok olabilir. Yer 'oluşması' değil yere 'dönüşmesi' olarak tanımlanan bu çözüm, konunun bir yitimden kaynaklanmasına dayanmaktadır. Yani kısacası, söz konusu yersizlik problemi yoktan var olmamakta aksine var olanın kaybolması/ bozulması sebebiyle ortaya çımaktadır. Bu sebeple problemin çözümü de ya bir geri dönüş ya da bir yıkımı gerektirmektedir.

Ahlat Ağacı filmi aracılığıyla da görülmüsstür ki filmler mekânın «yer〉 olma özelliğini eleştirel bir argüman olarak güçlü bir biçimde kullanmaktadır. Sinema her ne kadar insana ve topluma odaklanan bir sanat dalı olsa da; filmler, hem kendi eleştirel çerçevesi hem de mimarlık eleştirisi anlamında güçlü yaratımlardır. Bu eleştirel yön çalışmada, sinema-mimarlık ilişkisinde "ruhun yitimi" olarak adlandırılan özgün bir toplumsal eleştiri boyutuna dikkat çekmektedir. "Ruhun yitimi" kavramı Norberg-Schulz'un "Yerin Ruhu (Genius Loci)" kavramı ile farklı anlamsal incelemeler neticesinde ortaya çıkan "yersizlik" kavramının kesiştirilerek tekil bir teorik çerçeveye dönüştürülmesiyle ortaya çıkmıştır. Ruhun yitimi; yerin ruhunun yitimi peşi sıra insanın o 〈yerdeki r ruhunun ve paralelinde toplumun ruhunun yitimidir. Ruhun yitimi kavramı, yersizleşmenın hem nedeni hem de bir sonucudur. Sonuç olarak ruhun yitimi: Toplumsal bir oluşumdur ve yalnızca bireye içkin bir durum değildir; yersizleşme çizgisinin zaman içindeki değişimlerine bağlı olarak modernist ve postmodernist dönemde şekil değiştirmiştir, fakat yok olmamıştır.

Mekansal anlamda yerin, toplumsal yaşam anlamında da insanın ruh yitimi gerçekleştikten sonra gelecek her yeni, yeni-den üretim temelsiz ve bir boşluk içinde olacaktır. Tüm sosyal yurtlukların ve kodların iflası üzerine kurulu olan kapitalizmin (Koçyiğit,2007, s.124), 'ruhun yitimi' nden beslendiğini söylemek yanlış olmayacaktır. Bu eleştirel boyut hem mimarlık hem de mimarlık-sinema ilişkisi açısından oldukça önemli bir noktada konumlanmaktadır. Çünkü bireye ve topluma nitelikli, biricik ve kimlikli yaşam alanları yaratma ereğiyle varlığını sürdüren mimarlık, çalışma boyunca incelenen anahtar kelimeleri bünyesinde barındıran mekanlar yarattıkça veya mekanları (geri) dönüştürdükçe ruhu olan 'yer'ler üretilmiş olacaktır. Mimarlığı ulvi bir noktaya yerleştiren bir görüş olarak yorumlanabilecek olsa da mekan üretimi konusunda toplum yapısı ve kültürün başat noktada olduğu unutulmamalıdır. Bu sebeple toplumun ruhu; yeri, yerin ruhu da toplumu doğurmaktadır. Dolayısıyla bir yitiş söz konusu olduğunda bu yitiş de karşılıklı olmaktadır.

Yerin, bireyle ve paralelinde toplumla sıkı sıkıya bağlı olduğunu vurgulayan ve sosyolojik argümanı "Ahlat Ağacı" filmi aracılığıyla, ruhun yitimini okuyan bu çalışma devamında gelecekte; farklı filmler ve hatta farklı disiplinler ile mimarlık arakesitinde çeşitli anlamlar ve bağlamlar kurularak çalışmalar ve arayışlar yapılabilir.

\section{Çıkar Çatışması Beyanı:}

Makale yazarı herhangi bir çıkar çatışması olmadı̆̆ını beyan eder.

\section{Araştırmacıların Katkı Oranı Beyan Özeti:}

Yazarlar makaleye \%50 ve \%50 oranda katkı sağlamış olduklarını beyan ederler.

\section{Kaynakça}

Akbulut, H. (2005). Nuri Bilge Ceylan Sineması'nı Okumak Anlatı, Zaman, Mekân. İstanbul: Bağlam Yayıncılık.

Alkan Bala, H. (2019). Schindlerin Listesi Soykırım Öyküsünden Sinema-Mimarlık Arakesitinde Berlin Yahudi Müzesi Mekânsal Çözümlemeleri. SineFilozo i Dergisi,(2019 Özel Sayl): 53-74. 
Auge, M. (2017). Yok-yerler: Üstmodernliğin Antropolojisine Giriş. (T. Ilgaz, Çev.) İstanbul: Daimon Yayınları.

Avcı, M.G.\& Kıran, E. (2019). Ahlat Ağacı: Taşrada Dönüşümü İzlemek. Sinecine, 10(2), 241-262

Bachelard, G. (1996). Mekânın Poetikası (A.Derman, Çev.) İstanbul: Kesit Yayıncılık.

Bazin, A. (2011). Sinema Nedir?. (İ. Şener, Çev.) İstanbul: Doruk Yayınları.

Beşışık, G. (2013). Sinema Ve Mimarlıkta Mekân Kurgusu Ve Kavrayışı. ( Yüksek Lisans Tezi). Dokuz Eylül Üniversitesi Fen Bilimleri Enstitüsü, İzmir.

Ceylan, N. B. (2018, 05 27). Sevilmesi zor bir karakter kurmak önemliydi. (N. Kural, Röportaj Yapan) milliyet.com. 11 14, 2020 tarihinde https://www.milliyet.com.tr/pazar/sevilmesizor-bir-karakter-kurmak-onemliydi-2676671 adresinden alınd1.

Deleuze, G. (1997). Cinema 2 Time-Image. (H. Tomlinson, \& R. Galeta, Çev.) Minneapolis: University of Minnesota.

Deleuze, G. (2014). Sinema 1 Hareket-İmge. (S. Özdemir, Çev.) İstanbul: Norgunk.

Demir, S.T (2020). “Ahlat Ağacı" nın gölgesinde, kentin ve taşranın ötesinde: modern gündelik yaşamda bıkkınlık ruh halinin yükselişi. Humanitas, 8(15), 64-80.

Diken, B., Gilloch, G., \& Hammond, C. (2018). Nuri Bilge Ceylan Sinemast: Türkiyeli Bir Sinemacının Küresel Hayal Gücü. İstanbul: Metis Yayınları.

Ergin, S. (2007). Mimarlik ve Sinema Etkileşiminin Sinemasal Mekâna Etkileri ve Nuri Bilge Ceylan Sinemasindan Bir Örnek: "Uzak", Yüksek Lisans Tezi, Eskişehir: Anadolu Üniversitesi Fen Bilimleri Enstitüsü.

Ergül, Ö.H. (2003), “Heidegger'in Varoluşçu Ontolojisi”, Kayg̨ Dergisi.

Groh, J.M. (2021). Mekan Yaratmak. (G. Koca, Çev.) İstanbul: Metis Yayıncılık.

Giddens, A. (1994). Modernliğin Sonuçları. (E. Kuşdil, Çev.) İstanbul: Ayrıntı Yayınları.

Heidegger, M. (1971). Building Dwelling Thinking. M. Heidegger içinde, Poetry, Language, Thought (s. 145-152). New York: Harperperannial.

Heidegger,M. (2004). Varlık ve Zaman. (A. Yardımlı, Çev.) İstanbul: İdea Yayınevi.

Koçyiğit, R. G. (2007). Mimarlıkta Yersizleşme ve Yerin -Yeniden- Üretimi. Doktora Tezi. MSGÜ Fen Bilimleri Enstitüsü.

Lefebvre, H. (2014). Mekanın Üretimi. (I. Ergüden. Çev.) İstanbul: Sel Yayıncılık.

Monaco, J. (2002). Bir Film Nasıl Okunur? Sinema Dili, Tarihi ve Kuramı. (E. Yılmaz. Çev.) İstanbul: Oğlak Yayıncılık.

Öztürk, S. (2018). Ahlat Ağac1: “Yüce Dış Ses”in Kuşattı̆̆ı Film. SineFilozofi Dergisi: 226-229.

Pallasmaa, J. (2008, Eylül). Sinema ve Mimarlık. (I. Külekçi, Çev.) Arkitera Gündem. https:// v3.arkitera.com/g143-sinema-ve-mimarlik.html?year=\&aID=2621 sayfasından erişilmiştir. 
Relph, E.(1976), Place and Placelessness, Pion, London.

Schulz, C. N. (1980). Genius Loci: Towards a Phenomenology of Architecture. New York: Rizolli.

Sharr, A. (2010). Mimarlar için Heiddeger. (V. Atmaca, Çev.) İstanbul: YEM Yayınları.

Simmel, G. (2009). Bireysellik ve Kültür. İstanbul: Metis Yayınları.

Suner, A. (2005). Hayalet Ev: Yeni Türk Sinemasinda Aidiyet, Kimlik ve Bellek. İstanbul: Metis Yayınları.

Tekeş, K. (2019, Ocak 19). Koza'dan Ahlat Ağacı'na Nuri Bilge Ceylan Sinemasına Kısa Bir Bakış (II). Biamag: https://m.bianet.org/biamag/sinema/204611-koza-dan-ahlat-agaci-na-nuribilge-ceylan-sinemasina-kisa-bir-bakis-ii adresinden alındı.

Töle, H.M. (2019). Ahlat Ağacı ve Var-Kalma Çabası. SineFilozofi Dergisi, (2019 Özel Sayı) 5-25.

Usta,G. (2020). Mekân ve Yer Kavramlarının Anlamsal Açıdan İncelenmesi. The Turkish Online Journal of Design, Art and Communication - TOJDAC, 25-30.

Uzunkaya, A. (2014). "Yer" ve "Yersizlik" Kavramlar Üzerine Bir İrdeleme. Yüksek Lisans Tezi. İstanbul: Yıldız Teknik Üniversitesi Fen Bilimleri Enstitüsü. 